\title{
Közös erővel az egészségért. Beszámoló a marosvásárhelyi Egészségfejlesztés konferenciáról
}

\author{
Together for health. Report from the Conference for Health Promotion \\ in Marosvásárhely
}

\author{
Szerző: Sántha Ágnes $\bowtie$ \\ Sapientia Erdélyi Magyar Tudományegyetem, Marosvásárhelyi Kar, Alkalmazott \\ Társadalomtudományok Tanszék
}

Beküldve: 2018. 10. 16.

doi: $10.24365 /$ ef.v59i5.368

Kulcsszavak: egészségfejlesztés, közegészségügy, egészségi egyenlőtlenségek, kortársoktatás

Keywords: health promotion, public health, health inequalities, peer education

Sokat hallunk és beszélünk az egészség fejlesztésének fontosságáról. Sokan vannak azok is, akik tudományos megalapozottsággal tesznek az egészségi állapot javulásáért, a betegségek megelőzéséért. Az egészségtudományokban néhány évtizede uralkodó paradigma, az egészség megőrzése és fejlesztése állt az Egészségfejlesztés konferencia középpontjában is. A szervezők, a Sapientia Erdélyi Magyar Tudományegyetem és a Semmelweis Egyetem Egészségügyi Közszolgálati Kar olyan fórumnak képzelték el az eseményt, melyen az egészségfejlesztéssel elméletben és gyakorlatban foglalkozó szakemberek kutatásaikat, illetve fejlesztő tevékenységeik tanulságait megosztják egymással, az akadémiai közösséggel és a szélesebb hallgatósággal.

A rendezvénynek az egyetem új, a közelmúltban felavatott épülete adott otthont. A megnyitó plenáris előadáson az erdélyi magyarság népesedési perspektíváit villantotta fel dr. Ábrám Zoltán, a Marosvásárhelyi Orvosi- és Gyógyszerészeti Egyetem tanára, európai kontextusba helyezve a népességfogyás jelenségét és a kedvezőtlen demográfiai kilátásokat, az egymást követő generációkban fellelhető családalapítási minták változását.

Hely hiányában nem áll módunkban a 19 elhangzott előadás mindegyikét dicsérő szavakkal illetni, ám valamennyi kutatás tudományos alapokon nyugvó, egészségfejlesztő tevékenységet mutatott be, vagy annak szükségességét hangsúlyozta.

A szekcióülések közül kettő a foglalkozási csoportok, illetve etnikai-társadalmi csoportok egészségmagatartását és egészségi állapotát járta körül. $A z$ előadások egy része egyetemi kutatómúhelyek munkájának hozadéka: az egészségügyi ápolók egészségmagatartását, társadalmi-gazdasági helyzetét és hivatástudatát az idei évben a Sapientia EMTE Életminőség kutatóközpont vizsgálta (előadó Lukács-Márton Réka), az orvostanhallgatók kézhigiéniás szokásainak tanulmányozása a MarosvásárheIyi Orvosi és Gyógyszerészeti Egyetem projektje volt (előadó Gál Emőke). Ez utóbbi téma aktualitását

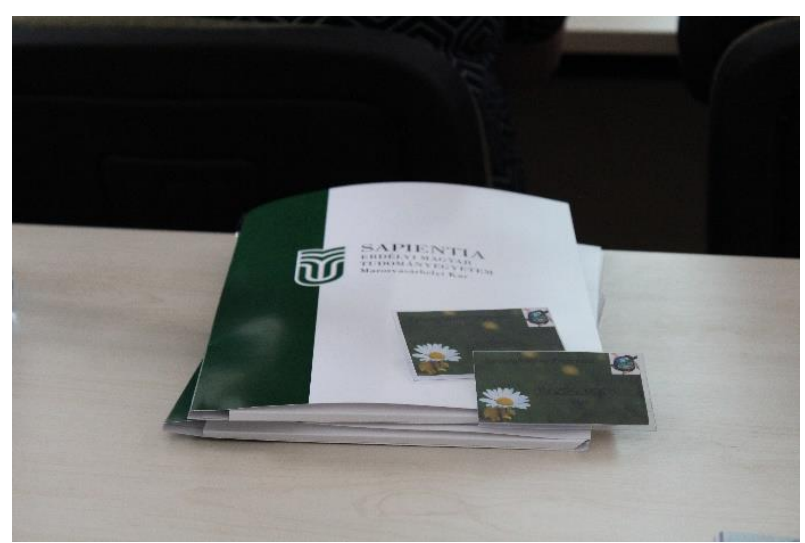


Semmelweis Ignác halálának 200. évfordulója adta. Elhangoztak olyan előadások is, amelyek az egyetemi kutatómúhelyek közötti tudományos együttmúködés eredményei: Kocsis Éva, a Pécsi Tudományegyetem doktorandusza és a Sapientia EMTE Makovecz-ösztöndíjasa a roma életminőség és egészségi állapot kutatójaként, összehasonlító vizsgálatról számolt be a hátrányos élethelyzetû roma népességben. Harangus Katalin (Sapientia EMTE) előadása a digitális egészség manapság divatos témájából az internetes információkeresés részterületét érintette, kiemelve annak előnyeit és hátrányait.

A gyakorlati egészségnevelő programokat bemutató előadások javarészt a budapesti TANTUdSZ munkacsoport tevékenysége köré összpontosultak.' Kétéves tevékenységükből a kézhigiénia és a folyadékfogyasztás fontosságát hangsúlyozó iskolai egészségnevelő programok emelkednek ki. Ezek eredményeit és egészségpedagógiai vonatkozásait emelte ki Soósné dr. Kiss Zsuzsanna, valamint két, a programban egyetemi hallgatóként részt vett kortársoktató (Benke Fruzsina Erika és Bordás Dorina) előadása. A TANTUdSZ kutatócsoport kézmosó programjában immár a Sapientia EMTE Életminőség kutatóközpontja is részt vesz, kisebb léptékű pilot projektet valósít meg a Maros megyei kisiskolások körében, és egzakt módszerekkel méri az egészségfejlesztő program hatékonyságát.

Marosvásárhely testvérvárosában, Nyíregyházán 2008 óta rendszeresen végeznek a lakosság körében kérdőíves egészségfelmérő vizsgálatot. A legutóbbi, idei adatfelvételbe már egészségmüveltségi kérdések is belefértek. Ennek tanulságait osztották meg a hallgatósággal Jávorné dr. Erdei Renáta és Barcs Anita, a Debreceni Egyetem Egészségügyi Karának oktatói, felhívva a figyelmet az egészségmúveltség erős társadalmi meghatározottságára, a még mindig jelenlevő társadalmi egyenlőtlenségekre.

A közvetlen hangulatú eseményen őszinte kíváncsisággal fordultunk egymás munkája felé. A népegészségügy szakmai kihívása az egészség pozitív szemléletét tovább alakítani, a megelőzés fontosságát tudatosítani, annak reális, elfogadható és terjeszthető gyakorlatát a legkülönbözőbb népességcsoportokban meghonosítani, kis lépésekben. Ezek egyike volt a bemutatott Egészségfejlesztés konferencia.

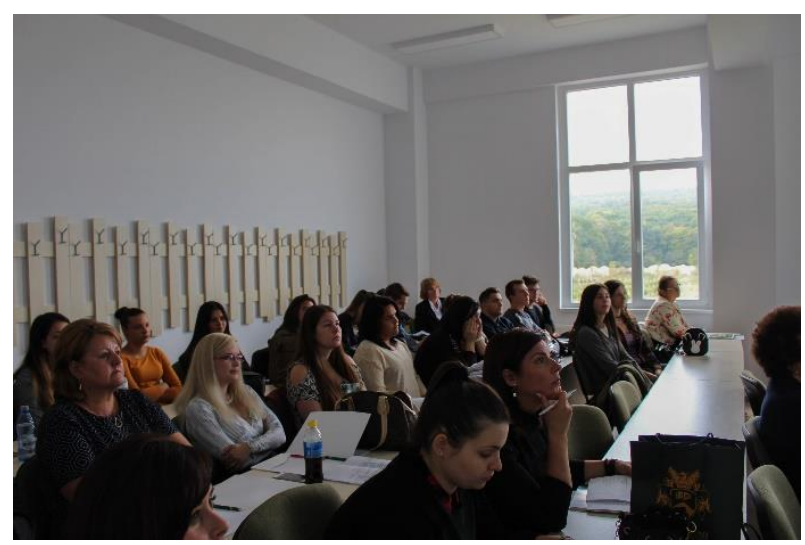

i Az MTA szakmódszertan pályázata által támogatott, MTA-SE Egészségnevelés kortárs-oktatással (TANTUdSZ) kutatócsoport vezetője dr. Falus András akadémikus, tagjai a Semmelweis Egyetem Egészségtudományi Karának és az Eötvös Loránd Tudományegyetem Tanító- és Óvóképző Karának oktatói és hallgatói. 